\title{
Economic benefits of foreign sourced germplasm in domestic crop improvement program: a case of an improved Khumal-4 rice variety in Nepal
}

\author{
D Gauchan ${ }^{1}$, KP Pant $^{2}$ and BK Joshi ${ }^{3}$ \\ ${ }^{1}$ Bioversity International, Kathmandu, Nepal, ${ }^{2}$ Food and Agriculture Organization, \\ Kathmandu \& ${ }^{3}$ National Agriculture Genetic Resources Centre (NAGRC), Khumaltar,
}

Nepal

Email: d.gauchan@cgiar.org

\begin{abstract}
This study assesses economic benefits of international exchange and flow of key rice germplasm in Nepal under globally operated multilateral system of facilitated access using a case of an improved rice variety Khumal-4. Khumal-4 rice is popular and widely grown in mid hills region of Nepal which was developed by crossing a high yielding dwarf foreign sourced germplasm IR-28 with a local Nepali variety Pokharilo Masino. Economic benefits of Khumal-4 rice adoption and impact was analysed using economic surplus model, where additional productivity and profitability gained from developing Khumal-4 was estimated in monetary value in comparison with existing farmers' variety Pokharilo masino. The finding showed that Khumal-4 covered $9 \%$ of rice area in the mid-hills and $7 \%$ in the mountains during year 2010-12 years covering about 40 thousand hectares of rice area. Data show that there is a clear yield gain of $1.25 \mathrm{mt}$ per hectare with cost in rice yield equivalent when farmers switch from traditional Pokhareli Masino to improved Khumal-4 variety. Estimation of additional revenue per hectare with total adoption area of Khumal-4 in prevailing market price in Nepal was NRs 1.07 billion (US \$ 11 million) per annum. This is reasonable economic benefits obtained annually from flow of foreign sourced genes (IR-28) for the development of an improved Khumal-4 rice variety in Nepal. This finding indicates that access to foreign germplasm is important for ensuring national food security and gaining higher economic benefits in the country.
\end{abstract}

Key words: adoption, economic benefits, facilitated access, foreign sourced germplasm

\section{Introduction}

Humanity has benefitted a lot from the exchange of plants, animals and their genetic resources from different parts of the world. Exchange of germplasm by breeders is at much higher rate than the exchange of plants and animals by general people. Plants, animals and their germplasm used to be transferred freely from country to country formally or informally before the advent of Convention of Biological Diversity (CBD) in 1992. The CBD conferred national sovereign rights to the genetic resources a country is having (CBD, 2001). The transfer is possible bilaterally with case by case agreement for material transfer. This provision slowed the rate of transfer of plants, animals and their germplasm adversely affecting breeding programmes. Plant breeders need genetic materials that are improved by others-breeding materials developed by other professional breeders and 
landraces selected and maintained by farmers. Without a smooth flow of genetic resources among the research and breeding stations, breeding programs and food production to feed the growing world population is a big challenge. For maintaining plant breeding programs for food production, members of Food and Agricultural Organization enacted International Treaty on Plant Genetic Resources for Food and Agriculture (ITPGRFA) in 2001, nine years after the CBD, with a provision of multilateral system (MLS) of material transfer (FAO, 2001).

The rationale behind the implementation of ITPGRFA and adoption of multilateral system (MLS) globally is to facilitate easy exchange and sharing of genetic resources across the countries (Gauchan et al., 2015). Article 13 of the ITPGRFA recognizes the benefits of facilitated access to plant genetic resources for food and agriculture (PGRFA) which are included in the MLS (FAO, 2001). Exchange and flow of valuable genetic resources containing in such PGRFA and incorporation of them to other varieties within and outside the countries is important for increasing food production to the benefit of global community. The international exchange of PGRFA has facilitated critical variety innovations in individual countries contributing significantly to agricultural productivity enhancement and ensuring national food security (FAO 2001; Evension and Gollin, 2003).

International exchange of germplasm for crop improvement generates appealing rates of return (Echeverria 1990, Alston et al., 2000, Evenson 2001). Evenson and Gollin (2003) reports that there is a high economic benefits from plant breeding research particularly through incorporation of genes from international sources to national programs. Major staples like rice, wheat and maize have benefited more from the foreign sources of genetic resources than non-staple crops. According to Hossain et al (2003) annual gains from adoption of improved rice varieties in Asia stood about US \$ 10.8 billion. The amount was nearly 150 times higher than annual investment made in rice research by International Rice Research Institute (IRRI) and National Agriculture Research Systems (NARS) together. The rate of return from wheat breeding research particularly from flow of international germplasm in Nepal also estimated to be high. Morries et al (1995) estimate about a high internal rate of return (IRR) of 85\% from wheat breeding research in Nepal from 1960 to 1995 that promoted improved wheat germplasm from international sources. Pant et al (2011) report that rice consumers in Nepal value for aromatic trait of rice much higher (US\$ 153 million) than the tasty trait (US\$ 28 millions) available in landraces locally available in the country. A recent Australian Centre for International Agricultural Research (ACIAR) impact study (Brennan and Malabyabus, 2011) of rice varietal yield improvement research from 1985-2009 from IRRI supplied germplasm in three East Asian countries, Philippines, Indonesia and Vietnam indicated a high economic rate of return with average yield gains of $11.2 \%$ per annum that was possible mainly from development of high yielding rice derived from externally sourced germplasms. The economic value of 
that yield improvement was estimated to be of US\$1.46 billion averaged per year across the three countries (Brennan and Malabyabus, 2011).

These values mentioned above provide overall economic benefits of improved crop germplasm for the whole improved varieties. However, we have no empirical studies carried out in the country to date for estimating benefits of international exchange and access of rice genetic resources with specific case varieties at the international and national level. Therefore, there is a need to study and identify the benefits accruing to Nepal from the use of foreign-sourced germplasm in new crop varieties widely cultivated and adopted by the farmers. Furthermore, information is scant about impact of use of both local landraces and foreign sourced germplasm in combination in crop improvement particularly for rice. This is especially important for a development country like Nepal where easy access and availability of diverse range of germplasm through own ex situ conservation, characterization and crop improvement programs is difficult due to absence of welldeveloped ex situ facilities and pre-breeding research activities. Moreover, continuous development, maintenance and adoption of new cultivars at the farm level is necessary for adaptation to climate change and increasing food production for ever increasing population (Rosegrant and Cline, 2003). In this context, the study aims to assess economic benefits of flow of improved rice germplasm and its use in local crop improvement in Nepal using a case study of Khumal-4 variety which is popular and widely grown in the mid-hills region (900-1500 msl) of Nepal (MoAD, 2014).

Since, rice is the principal food staple and major source of livelihood of two-thirds of the agricultural households, the facilitated exchange and use of the rice germplasm in crop improvement plays important role in national food security and household livelihoods in Nepal. Rice was selected for the case study as it is the number one food crop covering half of the country's area and accounting for more than half of the food production in the country (MoAD, 2014). Among the most popular rice varieties namely Radha-4 and Sabitri in Terai and Khumal-4 in mid hills and mountains, we choose Khumal-4 rice variety for the case study to assess economic benefits because it has been developed through domestic plant breeding by incorporating both external (e.g. IR 28) and indigenous germplasm (e.g. Pokhreli Masino) for mid-hill region of Nepal (Gauchan et al., 2015). In addition, information sources and existing survey data were available for this crop variety for analysis of variety innovations to estimate adoption level and assess economic benefits in the country.

\section{Methodology}

\section{Data sources}

The study employed use of various sources of data from existing household adoption studies, expert consultation meeting, desk studies and pedigree analysis. Pedigree analysis 
of the Khumal-4 variety has been carried out to identify and track the source of major gene for these varieties from various national and international exchanges. Adoption data are derived from recent survey of socioeconomic research of Nepal Agriculture Research Council (NARC) Socioeconomics \& Agricultural Research Policy Division (SARPOD) mainly from IRRI supported projects (Gautam et al., 2013; Gauchan et al., 2014; Velasco et al., 2014). The supplementary information that was not available on existing survey data was collected through field survey conducted in 2012-14. Comparative yield data from both improved varieties derived from foreign sourced germplasm and existing local variety with locally sourced germplasm are collected and compiled. The needed sources of information were supplemented through various literature review and desk studies.

\section{Economic framework for estimating benefits}

The economic methods of estimating benefits of improved variety derived from external and locally sourced germplasms can be analysed by different economic methods and tools. The more common methods of economic assessment of benefits belong to three main groups: the econometric methods, the programming methods and the consumer surplus methods (Masters et al., 1996). Considering the availability of data and information sources, we use here economic surplus measure to assess economic benefits of improved varieties that have gene from external sources received from international exchange and flow in Nepal. Market price method, proxy price methods and stated preference methods are generally used in estimation of economic surplus. Economic surplus measure using market price method is a robust method for estimation of benefits. This method permits the estimation of the economic benefits generated by adoption of a new variety compared to the situation before the adoption. The benefit of a new variety for the society will be the sum of the producers' surplus due to decrease in cost of production per unit of output and consumers' surplus due to decrease in price of the product. This method requires information on productivity increase generated by the new variety, equilibrium price of the product, adoption rate and costs, timeframe between research and adoption (Maredia et al; 2000).

Under the economic surplus approach, the area affected by incorporation of genes from foreign sources through plant breeding program can be measured either indirectly (in the form of a shift in the supply curve, which implicitly reflects changes in area planted) or directly (by estimating the rate of adoption of improved variety derived from external sourced germplasm and applying this rate of adoption to the area planted to the crop). The main advantage of using the economic surplus method is that the model needs less information than the other models (Alston et al., 1998; 2000). The economic surplus approach permits the estimation of the economic benefits generated by adoption of new variety innovations, compared to the situation before (without) the adoption, where only traditional variety innovation was available (Morries et al., 1992; Morries and Heisey, 2003). Benefits over the base area were estimated using the conventional method of 
multiplying the genetic gains attributable to improved variety (in this case, the yield losses foregone) times the area planted to modern varieties (MVs) derived from foreign sourced germplasm. The benefits that would be foregone in the absence of the variety innovation will provide a measure of the opportunity cost of not engaging in international PGRFA exchange.

\section{Parameters needed to calculate value of additional production}

The study estimated the value of the additional rice production attributable to breeding efforts of Khumal-4 as a result of international flow of germplasm. The economic effects of this improvement in variety can be measured in terms of incremental gain in yield and net returns (profitability). Once the area under Khumal-4 was estimated, the productivity gains in Khumal-4 from its original local parent Pokhreli Masino was compared to attribute yield gains from foreign source germplasm (IR-28). In order to calculate the value of the additional rice production attributable to international rice germplasm flows from breeding efforts, three key parameters were estimated: (1) the area planted to improved variety (2) the productivity gains attributable to adoption of improved rice variety, and (3) the price of rice grain. Using a simple economic surplus model, these three parameters can be combined to calculate the value of additional production in a given period $(t)$ :

$$
B t=A t(y t-C t) P t
$$

Where, $\boldsymbol{B}=$ value of additional production attributable to rice breeding research obtained from foreign sourced MLS germplasm,

$\boldsymbol{A}=$ area planted to chosen rice variety developed using foreign sourced germplasms,

$\boldsymbol{y}=$ yield gain attributable to rice breeding research obtained from foreign sourced germplasm

$\mathrm{C}=$ Additional cost of production of improved variety over the local variety expressed in rice equivalent

$\boldsymbol{P}=$ farm gate price of rice grain of designated variety.

The average yield of Pokhreli Masino obtained from field survey was used to compare with average yield of Khumal-4. Based on this the productivity gains attributable to adoption of Khumal-4 was estimated. Using the farm gate price of both the varieties obtained from field survey, the net additional value (in NRs) was estimated from the rice breeding research obtained from international genes (IR-28) in local Pokhreli Masino rice variety (see details Gauchan et al., 2015). 


\section{Results and discussion}

\section{Development and popularity of Khumal-4 rice variety}

The variety Khumal-4 was developed from domestic plant breeding combining genes from both local and foreign sourced germplasms. It was developed by crossing popular dwarf high yielding and disease tolerance exotic rice variety IR-28 obtained from IRRI Philippines with popular indigenous Pokhareli Masino that has unique grain quality with good taste, fine grains, taller plant height and traits of local adaptation. Khumal-4 (NR 10078) was released in Nepal in 1987 by crossing IR-28 with Pokhareli Masino (Joshi et al, 2005; Joshi, 2008). It has intermediate plant height with good yield and grain quality and it is popular among urban consumers and sold in the brand name of Pokharilo Jira Masino or Jira Masino due to its good eating and cooking quality and growing market demand. It currently fetches good price in the market and sold in different names of fine rice and brand names. It is officially released in 1987 and being cultivated widely in mid hill region from east to far western region. Hence, it is most popular among farmers in the mid hills (800-1500 msl) of Nepal and among consumers in Kathmandu valley and other hill urban centers because of its good grain quality (Gauchan et al., 2015).

\section{Pedigree analysis}

The pedigree analysis of rice variety Khumal-4, popular in the hills of Nepal that contains externally incorporated genes received from various foreign sources. Khumal-4 is derived from 13 landraces originated in 8 different countries (USA, India, Indonesia, Taiwan, China, Pakistan, Thailand and Nepal) (Joshi et al., 2016). The details of pedigree tree of Khumal-4 with their parentage and their percent coefficient of parentage traced back to the ancestors (in oval shape) are given in Figure 1 (Joshi, 2013). Khumal-4 has genic portion of 50\% of Pokharilo Masino, 12.5\% of GP15 and remaining percent from 11 landraces. Khumal-4 (NR-10078) was released in 1987 by crossing IR-28 with Pokhreli Masino (Joshi, 2008). The IR-28 was originally developed in IRRI from many crosses that were originated from germplasm derived from Taiwan, India, Indonesia, Thailand and USA. IR28 has dwarfing gene i.e. DGWG (derived from Taiwanese variety) and high yielding traits from IR-8 (IRRI). 


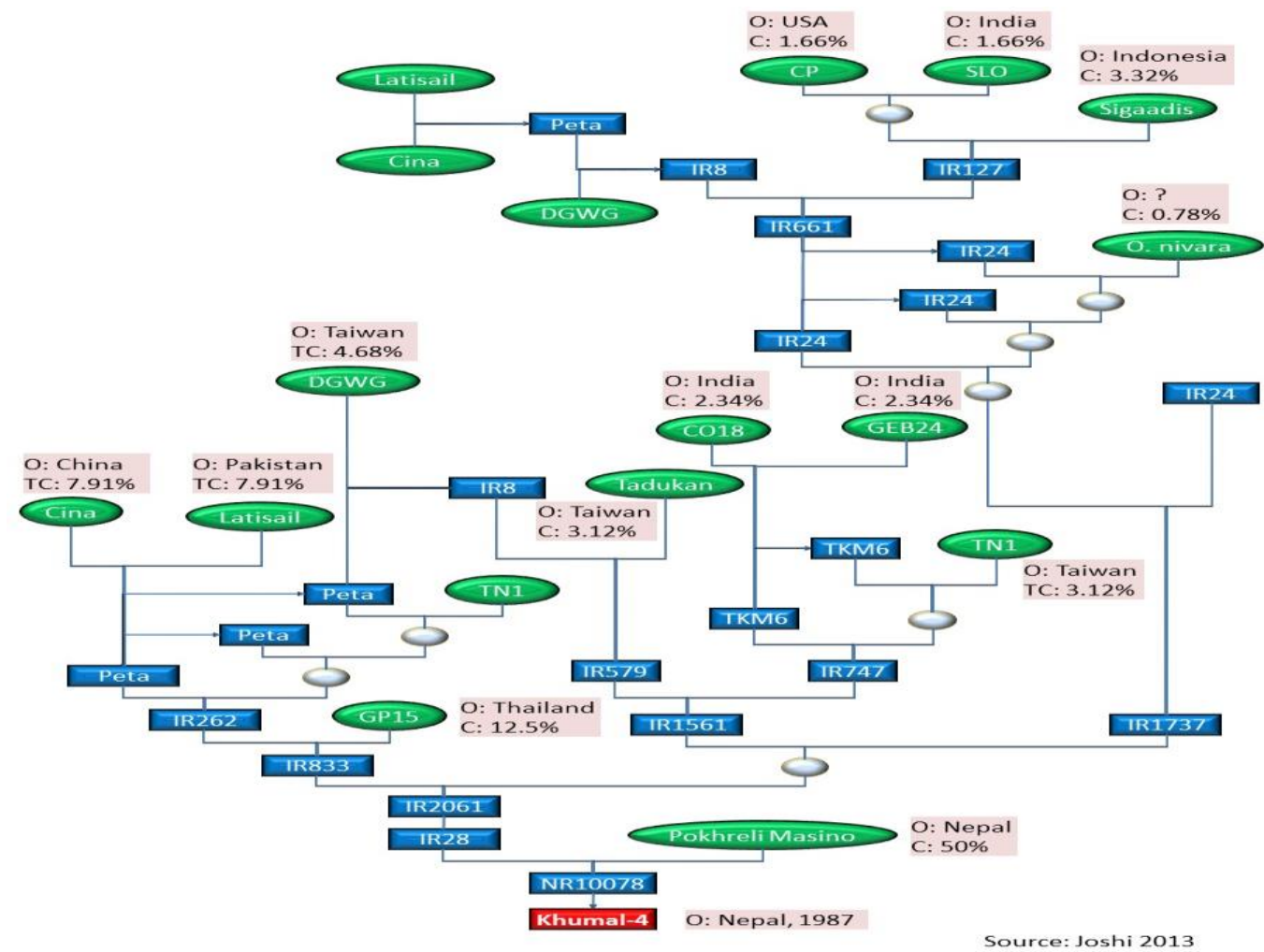

Figure 1. Pedigree tree of Khumal-4 rice variety with their parentage. Traced back to the ancestors (in oval shape) that had no known relationship. $O$, origin; C, contribution

\section{Farm level adoption of Khumal-4 rice variety}

Adoption reflects the farmers' decision to incorporate improved varieties into their existing production system by replacing traditional varieties (TVs) or by replacing improved varieties of older vintage that were adopted earlier (Gauchan et al., 2012). We used available farm level survey data to estimate and analyse farm level adoption of Khumal-4 in Nepal. Available survey revealed that the extent and pattern of adoption of Khuma-4 variety varied across different districts in Nepal (Gautam et al., 2013). Out of 29 districts surveyed in Tracking Rice Variety for South Asia (TRIVSA) study of International Rice Research Institute (IRRI) in Nepal, there were 16 hills and 2 mountains districts in the sample survey in 2010-2012 (Velasco et al., 2014). Among them, the adoption of Khumal4 was observed in nine hill districts namely, Kavre, Bhaktapur, Dailekh, Lamjung, Parbat, Myagdi, Kaski, Gorkha and Baglung and in one mountain district namely Sankhuwasabha (Figure 2). The highest rate of adoption of Khumal-4 was found in Bhaktapur (42\%), Kavre $(41 \%)$ and Dailekh $(35 \%)$ districts. Shrestha et al (2012) reported that Khumal-4 covers 55\% of rice land in Kavre, 35\% in Dailekh, $25 \%$ in Doti, 12\% in Dhankuta and 5\% in Parbat. Khumal-4 was not reported from Jumla - a high mountain district and also some 
of the Hill districts (e.g. Udaypur) that have rice area in lower altitude belt $(<800 \mathrm{msl})$ river basins and lowland valleys. In aggregate Khumal-4 was adopted in $9 \%$ of the mid hills and 7\% of the mountain regions of Nepal in 2010-12 (Gauchan et al., 2015). No farmer reported cultivation of Khumal-4 was observed in Terai districts.

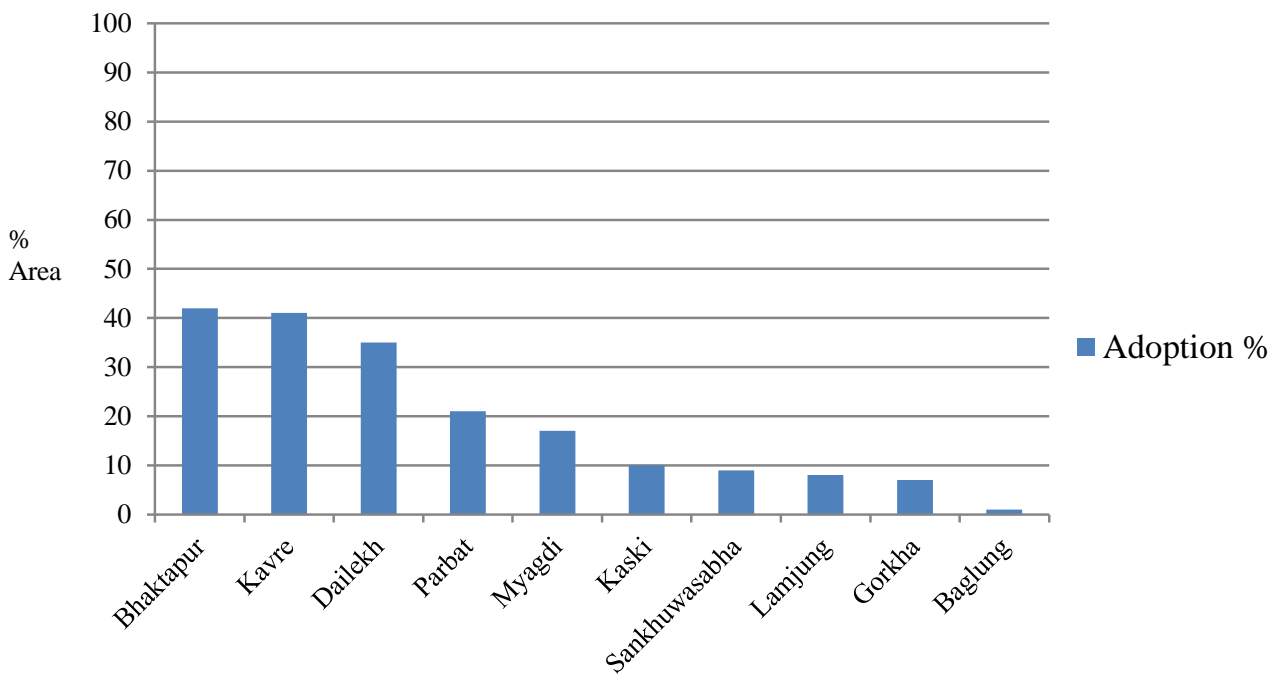

\section{Figure 2. Pattern of adoption of Khumal-4 in hills and mountain districts}

\section{Estimation of area under Khumal-4 rice}

In order to estimate economic benefits of a given variety, it is essential to have actual data on farm level area coverage of that specific variety for its production domains. This can be estimated from percent adoption (area coverage) of the variety from the actual rice area of the districts and domains for the specific point of time. Analysis of official data on average rice area for the three years (triennium) during survey period was compiled to estimate coverage of Khumal-4 (Table 1).

Table 1. Triennium average of rice area (2009-11) with estimated Khumal-4 coverage

\begin{tabular}{llllllll}
\hline Region & \multicolumn{2}{l}{ Rice Area (000 ha) } & \multicolumn{3}{c}{ Triennium average area } & \multicolumn{2}{l}{ Khumal area } \\
& & & & & & & \\
& 2009 & 2010 & 2011 & 1000 ha & $\%$ & $\%$ & 1000 ha \\
\hline Mountain & 65 & 67 & 68 & 67 & 4 & 7 & 5 \\
Hill & 393 & 407 & 395 & 398 & 26 & 9 & 36 \\
Terai & 1,098 & 1,023 & 1,068 & 1,063 & 70 & 0 & 0 \\
Nepal & 1,556 & 1,496 & 1,531 & 1,528 & 100 & & 41 \\
\hline
\end{tabular}

Source: MoAD (2011) and NARC TRIVSA field survey (2010-2012) 
Triennium average of rice area (2009-2011) indicated that, the rice area in hills and mountain regions was 398 thousand and 67 thousand hectares, respectively. This accounted for about $26 \%$ and $4 \%$ of the total rice area of Nepal in the hills and mountain respectively. In aggregate of hills and mountain regions, estimation showed that about 41 thousand rice area was covered by Khumal-4 during the study period (Gauchan et al., 2015). This was estimated from existing household survey data in Nepal which indicated that Khumal-4 covered $9 \%$ of rice area in the hills and $7 \%$ in the mountains during the survey year 2010-12.

\section{Estimation of value of additional rice production}

Table 2 presents comparative yields of Khumal-4 and Pokhreli Masino and actual estimation of the benefits from Khumal-4 in Nepal. Data show that there is a clear yield gain when farmers switch from traditional Pokhreli Masino to modern Khumal-4 variety. The gross yield difference between Khumal-4 and Pokhreli Masino was about $1.5 \mathrm{mt}$ per hectare with higher yield advantage for Khumal-4 that incorporates foreign sourced genes from different countries under MLS. Since the cost of production of improved varietyKhumal-4 is relatively higher than Pokhreli Masino, this higher cost of production should be adjusted. One of the best ways is estimation of yield in terms of cost in rice equivalent (Hossain et al., 2003). After adjusting cost in rice equivalent for both the varieties, the estimation showed that net yield gain from the adoption of Kumal-4 yield was $1.25 \mathrm{mt}$ per hectare. Though the transaction costs of germplasm transfer and breeding mostly done by public sector institutions are not fully included in the analysis, part of that cost is included in the sales of breeder and foundation seeds by the breeding institution. The costs of seed multiplication and marketing mostly done by the private sector are automatically included in the seed costs reflecting in the costs of production. In terms of net revenue, the additional revenue per hectare from Khumal-4 was NRs. 26, 250 (US \$ 275) per hectare. Based on the analysis of total revenue gains from Khumal-4 in 2010-11 price in Nepal was NRs 1.07 billion (US \$ 11 million). Although this estimate is somewhat crude, this is reasonable economic benefits obtained from incorporation of foreign sourced germplasm in Khumal-4 development, despite its relatively low aggregate adoption level in the hills and mountain regions in Nepal. This is because the suitability of Khumal-4 adoption was in the mid hill altitude range of 900-1500 msl not adapted well to lower hills where large rice area in the hills are located in river basins and lower altitude of hills.

Table 2. Comparative yield and revenue gain from foreign gene in Khumal-4

\begin{tabular}{lllllll}
\hline Variety & $\begin{array}{l}\text { Average } \\
\text { yield }(\mathrm{mt} \\
\text { /ha) }\end{array}$ & $\begin{array}{l}\text { Cost in rice } \\
\text { equivalent } \\
\text { yield*(mt /ha) }\end{array}$ & $\begin{array}{l}\text { Net yield gain } \\
\text { from adoption } \\
(\mathrm{mt} / \mathrm{ha})\end{array}$ & $\begin{array}{l}\text { Farm gate price } \\
(\mathrm{Rs} / \mathrm{mt})\end{array}$ & $\begin{array}{l}\text { Revenue (Rs } \\
\text { /ha) }\end{array}$ & $\begin{array}{l}\text { Total Revenue } \\
\text { (Rs million) }\end{array}$ \\
\hline $\begin{array}{l}\text { Khumal-4 } \\
\begin{array}{l}\text { Pokhreli- } \\
\text { Masino }\end{array}\end{array}$ & 3.50 & 1.25 & 2.25 & 25,000 & 56,250 & \\
\begin{tabular}{l} 
Difference \\
\hline
\end{tabular} & 1.00 & 1.00 & 30,000 & 30,000 & \\
\hline
\end{tabular}


*Note: Cost in rice equivalent yield was estimated based on actual cost of production data. We assume that Khumal-4 probably would have taken 13 years to reach current adoption level $^{2}$ in the mid hills (9\%) and mountain (7\%) since its release in 1987. Considering the adoption lags of 13 years, the variety has provided every year this amount of benefits in the last 15 years since the year 2000. The improved variety Khumal-4 also provides other nonyield or non-monetary benefits which we have not included in the above estimation. These include production stability as a result of disease tolerance and less lodging of the improved variety as compared to its traditional parent, Pokhreli Masino. In addition, its other benefits are reduction in the growing period (relatively shorter duration) that enables farmers to increase cropping intensity through cultivation of vegetables, wheat and cash crops.

The case study of an improved rice variety Khumal-4 showed that the real value added benefits in terms of incremental yield and profitability arising from facilitated access, use and exchange of PGRFA materials in plant breeding in the country is very high despite relatively low aggregate adoption level of Khumal-4 in hills and mountain regions in Nepal. Therefore, if Khumal-4 were not developed and promoted using foreign sourced germplasm (IR-28), the country would have lost these reasonable monetary and nonmonetary benefits implying high opportunity cost of not engaging in international PGRFA exchange. As $68 \%$ of rice varieties released in Nepal contains genes of foreign sources (Joshi et al., 2014), the benefits from transfer of rice genetic resources from foreign sources is very high in rice production and food security in the country. In addition to rice, many other crop species being presently grown in Nepal carry genetic resources from foreign sources. Major such crops that depend heavily on foreign genetic resources are wheat, maize, pulses and vegetables.

The present study provides broad overview of the benefits of foreign sourced germplasm in combination with local landraces in crop improvement. The above mentioned derived benefits are the combined effect of both foreign sourced germplasm (IR-28) and local landraces (Pokharilo masino) in addition to breeding efforts of NARC scientists. Hence the benefits obtained from Khumal-4 also contain benefits of interaction effect of local germ plasm Pokharilo masino with exotic germplasm IR-28. Disentangling actual benefit of sole IR-28 is difficult due to estimation difficulties.

\section{Conclusion}

The case study of an improved rice variety Khumal-4 showed that the real value added benefits, arising from facilitated access, use and exchange of PGRFA materials in plant

\footnotetext{
${ }^{2}$ The analysis of TRIVSA survey conducted in 29 districts across different agroecozones and development regions in Nepal showed that it takes about 12 years for a variety to reach in adoption level after its release from breeding program (Velasco et al., 2014; Gauchan et al., 2014).
} 
breeding in the country is very high. The incremental benefit derived from externally sourced germplasm in Khumal-4 variety is reasonably high, despite relatively low aggregate adoption level of Khumal-4 in hills and mountain regions in Nepal. The estimates showed that the incorporation of genetic resources incorporated in Khumal-4 provides benefits of about Rs 1 billion (US \$ 11 million) per annum at the current price and the farm level adoption of year 2010-2012. In addition, there are other benefits such as non-monetary benefits of increased production stability brought by its relatively better disease resistance and non-lodging nature including its suitability for growing subsequent crops due to its relatively shorter duration. Considering a high benefits of easy access of foreign source germplasm with the case of Khumal-4 rice, facilitated access from foreign countries under multilateral system is important to promote and sustain variety innovations in developing country like Nepal, where agricultural is critical to food insecurity and livelihood of the people. Therefore, if Khumal-4 were not developed with domestic plant breeding and promoted using foreign sourced germplasm (IR-28), the country would have lost these reasonable monetary and non-monetary benefits implying high opportunity cost of not engaging in international PGRFA exchange. Therefore, there is a need of facilitated access and exchange of germplasm under multilateral system. Moreover, there is an increased need for higher investment in plant breeding by incorporating foreign sourced germplasm in the existing indigenous germplasm to improve productivity and profitability of the crop as well as to improve adaptability of farming systems to changing climate conditions. This study estimates economic benefits of adoption of improved germplasm from one point of time due to lack of data availability for different periods. Estimation of economic benefits of foreign sourced improved germplasm for longer period would have given better estimates that use estimating financial measures of project worth, such as net present value (NPV) and internal rate of return (IRR). Estimating and accounting for the benefits of crop variety innovations requires detailed disaggregated data for variety adoption, yield, price, farm management and farm level information and use of complex analytical methods such as use of econometric techniques and statistical tools. Future studies need to focus more in-depth analysis and estimation using robust econometric tools and methods for estimating impact of plant breeding and variety innovations for deriving long-term benefits of improved rice variety innovation in the country.

\section{Acknowledgement}

This report is the part of the output of Genetic Resources Policy Initiative (GRPI)-Phase 2 project of Bioversity International funded through the Netherlands government that is being implemented in Nepal in partnership with NARC, MoAD and LI-BIRD. We are thankful to Dr. Ronnie Vernooy and Dr. Michael Halewood of Bioversity International, Rome for their overall technical support in conducting this study in Nepal. Mr. Madan Bhatta then GRPI-2 Project Coordinator, Ms, Rachana Devkota, Socio-economist, LIBIRD and all the team members of GRPI-2 Nepal project are gratefully acknowledged. 
The authors are also grateful to IRRI TRIVSA and STRASA projects implemented by NARC Socioeconomics \& Agricultural Research Policy Division (SARPOD) and IAAS, Lamjung campus for the data sources and support.

\section{References}

Alston, JM., GW Norton; and PG. Pardey. 1998. Science under scarcity: principles and practices for agriculture research evaluation and priority setting. Cornell University Press, Ithaca, NY, pp. 585

Alston, JM., C Chan-Kang; MC Marra; PJ Pardey; and TJ. Wyatt. 2000. A meta-analysis of rates of return to agricultural R\&D: ex pede Herculem, International Food Policy Research Institute, Research report No.113, Washington, D.C.

Asfaw, S and L Lipper. 2012. Economics of plant genetic resource management for adaptation to climate change. A review of selected literature, ESA Working paper No. 12-02, Food and Agriculture Organization (www.fao.org/economic/esa).

Brennan, JP and A Malabayabas. 2011. International Rice Research Institute's contribution to rice varietal yield improvement in South-East Asia. ACIAR Impact Assessment Series Report No.74.Australian Centre for International Agricultural Research.Canberra.111pp.

CBD. 2001. Hand book of the Convention on Biological Diversity (CBD). Secretariat of the

Convention on Biological Diversity (CBD). United Nation Environmental Program

(UNEP). Earth scan Publication, London

Echeverria, RG. 1990. Assessing the impacts of agricultural research. In: Methods for diagnosing research system constraints and assessing the impact of agri. research, Vol. II (R.G. Echeverria, ed).Assessing impacts of agricultural research. The Hague: ISNAR.

Evenson, RE and D Gollin. 2003. Crop variety improvement and its effect on productivity: the impact of international agricultural research. (RE Evenson and D. Gollin, eds) Growth (Lakeland). Oxon, UK; Cambridge, MA, USA: CABI

Evenson, RE. 2001. Economic impacts of agricultural research and extension, Chapter 11 In: Handbook of agricultural economics (B. Gardner and G. Rausser, eds).Volume 1. Elsevier Science.

FAO. 2001. International Treaty on Plant Genetic Resources for Food and Agriculture (ITPGRFA) in Nepal. Food and Agriculture Organization (FAO), Rome, Italy.

Gauchan, D; KP Pant; BK Joshi; and R Devkota. 2015. Benefits from international exchange. Mapping and measuring PGRFA flows and interdependence: The dynamics of the global crop commons; Theme 3.GRPI-2 Nepal project, Manuscript. Bioversity International, NARC, MoAD and LI-BIRD, Nepal. 
Gauchan D., DB Thapa Magar; S Gautam; S Singh; and US Singh. 2014. Strengthening seed system for rice seed production and supply in Nepal. IRRI-NARC collaborative EC-IFAD funded project on Seed Net Development. Socioeconomics and Agricultural Research Policy Division, Nepal Agricultural Research Council, Nepal. 40p.

Gauchan, D., HK Pant; S Gautam; and MB Nepali. 2012. Patterns of adoption of improved rice varieties and farm level impact in stress prone rainfed areas of Nepal. In: Patterns of adoption of improved rice varieties and farm-level impacts in Stressprone rainfed areas in South Asia (S. Pandey, D. Gauchan, M. Malabayabas, M. Bool-Emerick, B. Hardy, eds). Book, Los Baños, Philippines: IRRI. 318 p.

Gautam, S; HK Panta; ML Velasco; YN Ghimire; D Gauchan; and S Pandey. 2013. Tracking of improved rice varieties in Nepal. A draft report, IRRI TRIVSA (Tracking Rice Variety for South Asia) Project, Social Sciences Division, IRRI, Philippines and SARPOD, NARC and IAAS Lamjug Campus, Nepal.

Hossain, M; D Gollin; V Cabanilla; E Cabrena; N Johnson; G Khush; and G McLaren. 2003. International research and genetic improvement in rice: Evidence from Asia and Latin America. In: Crop variety improvement and its effect on productivity: the impact of international agricultural research. (RE Evenson and D. Gollin, eds).Growth (Lakeland). Oxon, UK; Cambridge, MA, USA: CABI

Joshi, KD., S Biggs; D Gauchan; KP Devkota; CK Devkota; PK Shrestha; and BR Sthapit. 2005. The evolution and spread of socially responsible technical and institutional changes in a rice innovation system in Nepal. CAZS Natural Resources, Discussion Paper No. 8. University of Wales, United Kingdom.

Joshi, BK. 2008. Diversity based on coefficient of parentage among rice cultivars recommended for mid and high hills of Nepal. SAARC J. Agric. 6(1):1-12. http://www.saarcagri.net/documents/download_SJA/sja_v_6_i_1/DIVERSITY.pdf

Joshi, BK., MR Bhatta; KH Ghimire; and D Singh. 2016. Mapping and measuring PGRFA flows and interdependence: Germplasm flows, Uses and determining factors. In: Mapping and measuring PGRFA flows and interdependence: Germplasm flows, uses and determining factors (BK. Joshi, P. Chaudhary, D. Upadhya and R. Vernooy, eds.) LIBIRD, NARC and Bioversity International (in press).

Joshi, BK. 2013. Pedigree tree of Khumal-4: How important multilateral system of access to national and international crop gene pools. NAGRC, Khumaltar. Poster.

Maredia, M and D Byerlee, eds. 1999. The global wheat improvement system: Prospects for enhancing efficiency in the presence of research spillovers. CIMMYT Research report No. 5. Mexico, D.F. CIMMYT.

Maredia, M., D Byerlee; and J Anderson. 2000. Ex post evaluation of economic impacts of agricultural research programs: A tour of good practice. Paper presented to the workshop on "The future of impact assessment in CGIAR: Needs, constraints, and 
options", standing panel on impact assessment (SPIA) of the technical advisory committee, Rome, May 3-5, 2000.

Masters, WA; B Coulibaly; D Sanogo; M.Sidibe; and AWilliams. 1996. The economic impact of agricultural research: A practical guide. Department of Agricultural Economics, Purdue University, West Lafayette, IN.

MoAD. 2011; 2012; 2013; 2014. Statistical Information on Nepalese Agriculture. Ministry of Agriculture Development (MoAD), Government of Nepal. Kathmandu, Nepal.

Morries, ML, and PW Heisey. 2003. Estimating the benefits of plant breeding research methodological issues and practical challenges. Agricultural Economics 29 (2003)241-252

Morris, ML, HJ. Dubin, and T. Pokharel. 1992. Returns to wheat research in Nepal. CIMMYT Economics working paper 92-04. Mexico, D.F.: CIMMYT.

Mortimore, MJ and WM Adams. 2001. Farmer adaptation, change and crisis in the Sahel. Global Environmental Change. 11(1) April: 49-57.

Pan, t KP; JC.Gautam; and E Wale. 2011. Valuation of rice diversity in Nepal: a traitbased approach, Chapter 3. In: the Economics of managing crop diversity on-farm case studies from the Genetic Resources Policy Initiative (E. Wale, AG. Drucker and KK. Zander, eds). Earthscan, London, pp 45-64.

Rosegrant, MW and SA Cline. 2003. Global food security: challenges and policies. Science 302, 1917-1919.

Shrestha, HK; HK Manandhar; and PP Regmi. 2012. Variety development cost versus variety adoption in major cereals in Nepal. Nepal Journal of Science and Technology 13 (1): 7-15

Velasco L., TW. Tsusaka and T. Yamano. 2014. TRIVSA synthesis report on rice. Tracking Improved Rice Varieties for South Asia (TRIVSA). International Rice Research Institute (IRRI), Philippines.August 2013. 